\title{
Prevention Effectiveness of Non-Performing Financing in the Indonesian Islamic Bank
}

\author{
Mutawali $^{1 *}$, Ahmad Rodoni ${ }^{2}$, Muhammad bin Said ${ }^{3}$ \\ ${ }^{*}$ Corresponding author
}

\begin{abstract}
Islamic banking still has a high ratio of non-performing financing. This study analyzes the causes of non-performing financing, along with the prevention effectiveness and resolution strategies performed by Islamic banks in dealing with this problem. Interviews conducted on nine informants, with questionnaires distributed to 30 respondents. The results show that the prevention effectiveness performed by Islamic banks consists of legal aspects, qualified human resources, and criteria assessment used to finance proposals, and improve risk management. Furthermore, internal factors such as default, information asymmetry, and financial stress were attributes of non-performing financing, which is externally influenced by inflation, GDP decline, natural disasters, interest rates, and political criminality.
\end{abstract}

Keywords: non-performing financing, prevention effectiveness, Islamic bank

JEL Classification: G21, G32

\begin{abstract}
Abstrak. Industri perbankan syariah masih memiliki kredit bermasalah. Penelitian ini menganalisis penyebab terjadi pembiayaan bermasalah, serta efektifitas strategi pencegahan dan penyelesaian pembiayaan bermasalah pada Bank Umum Syariah. Wawancara dilakukan kepada sembilan informan dan penyebaran angket ke 30 responden. Hasil penelitian ini menunjukkan efektivitas pencegahan yang dilakukan bank syariah saat ini terdiri dari peningkatan aspek hukum, pembentukan SDM berkualitas, pencegahan aspek nasabah dari sisi penilaian kritera saat mengajukan pembiayaan, dan pencegahan aspek menajemen yang peru dilakukan peningkatan manejemen dari sisi risiko pembiayaan. Penyebab terjadinya pembiayaan bermasalah disebabkan oleh faktor internal yang bersumber dari wanprestasi, asimetri informasi dan, tekanan keuangan. Pada sebab ektrenal dipengarubi dari kondisi inflasi, penurunan PDB, bencana alam, peningktan suku bunga, politik kriminalitas.
\end{abstract}

Kata Kunci: pembiayaan bermasalah, efektivitas pencegahan, perbankan syariah

\section{How to Cite:}

Mutawali., Rodoni, A., \& Said, M. (2019). Prevention Effectiveness of Non-Performing Financing in the Indonesian Islamic Bank. Etikonomi: Jurnal Ekonomi. Vol. 18 (2): 259 - 274. doi: http//dx.doi.org/10.15408/etk.v18i2.11262. 


\section{Introduction}

In Indonesia, the growth of Islamic banking tends to raise the problem associated with financial risks, which began in Thailand on July 2, 1997. Although it led to an increase in revenues and health by the East Asian countries, poverty rates have not decreased. These developments liberalized the finances and capital markets through international pressure, providing a negative effect on the crisis and raising various kinds of problems related to the capital issue. According to Winarto (2009), the emergence of this financial crisis caused by the existence of liberal manners, which saw the international market flow as an engine of growth for the economy and progress of developing countries. Furthermore, in 2006, the United States experienced a credit card crisis due to people's consumption patterns. Banks became bankrupt owing to low liquidity caused by public payment inability that requires government involvement.

During the 1997 and 2008 crisis, Islamic banks in Indonesia, had high intermediation and liquidity ratios, with excellent stock market performance. They also played a significant role in overcoming Pakistan financial crisis in 2008 due to its ability to give credit to customers (Farooq, 2015). However, Brunei Darussalam financial crisis was persistent from 2007-2010 due to liquidity, low deposit costs, and controlled banking stability. (Khaskhelly, 2015).

Islamic banks apply the principle of profit-sharing, and real transactions in financing products, with the profit, fixed and carried out proportionally to avoid high-interest rates. Besides, it also provides freedom from the negative spread. (Sutikno, 2009) Islam encourages Muslims to invest their money and become partners in taking risks and making profits in business (Kettle, 2011). Islamic finance is essentially interest-free and asset-based, with a structured ownership investment and payment mechanism used for making transactions furthermore, its basic framework based on Islamic elements and laws (Ryu, 2012).

The development of Islamic banking based on numerous established conventional financial industries. In 2016, 7 Islamic banks were established, with 21 banking business units, including Bank of Aceh (BAS), Bank of Muamalat Indonesia (BMI), Bank of BRI Shariah, Bank of Jabar Banten Shariah (BJBS), Bank of BNI Syariah (BNIS), Bank of Shariah Mandiri, Bank of Mega Shariah (BMS), Bank of Panin Shariah (BPS), Bank of Shariah Bukopin (BSB), Bank of BCA Shariah, Bank of Maybank Shariah Indonesia, and Bank of Tabungan Pensiunan Nasional Shariah (BTPNS) (OJK, 2016).

However, Islamic banks are recently experiencing poor finance owing to the inability of debtors to pay. Therefore, there is an adequate need to carry out preventive measures. Although financing is a significant source of bank profit, it is also associated with risk not only to banks but also to the customers (Antonio, 2009). Conversely, the new financing product launched in Islamic banks is less innovative, with limited funds, human resources, and an outstanding IT sector. Besides, a higher number of employees recruited were not from the Islamic economy or its boarding school. Although sharia bank is currently experiencing problems, its spread across Islamic and non-Islamic countries is still within a macro slowdown. By 2017, the market share increased by $5.44 \%$ (Statistic OJK, 2017) as opposed to its 4.86\% increment in 2016.

The non-performing financing problems in Islamic banks in Indonesia have a fluctuated NPF ratio over the past five years. In 2014, it was $4.34 \%$ and decreased to $3.03 \%$ in 2013. In the 
next year, it increased to $3.49 \%$ but decreased at the end of 2017 by $2.11 \%$. However, in March 2018, it increased by $2.46 \%$ (Sharia banking statistics", 2018). NPF is a reflection of problems in the banking and corporate sectors, as it tends to create issues for it to balance on the asset, using income statement as a result of allowance for credit losses (Agnes, 2010). High NPL in the banking system creates systemic risk, causes deposit panic, and limits financial intermediation.

Consequently, it limits the investment growth and decreases when combined with macroeconomics (Agnes, 2010). The increase in NPF significantly contributed to the bank's underperformance, which is one of its good indicators (Maidalena, 2014). Non-performing financing is not a "uni class" but a "multiclass" concept. It is classified based on the "long of overdue" loan. It is also seen as a secondary product specificity used during the financial crisis and the cause of poor bank performance (Parven, 2015).

According to Handoko (2009), these problems require prevention efforts as part of the planning process to avoid inconsistencies. Before a manager gives direction, planning, supervision, and the organization conducts preventive measures. One of the essential aspects of making decisions is to develop, and select activities to complete the problem. This prevention needs to be detected early before the financing activities because it requires clear policies which reveal the bank's credit risk management philosophy and parameters (Wanjira, 2010). Before completing problems associated with non-performing financing, preventive measures should follow with appropriate and accurate handling. Parven (2015), stated that problems associated with NPF occur due to the absence of a proper management strategy. The resolution of non-performing financing in the conventional bank located in Egypt conduct by Sahar Nasr (2007). It conducts to strengthen, restructure, improve and control bank governance, risks, as well as independent and comprehensive audits.

Hasan (2008) analyzed an unresolved problem in making credit control in sharia banking systems in Malaysia. According to Hasan (2008), credit is not Islamic, and Islamic banking has to be aligned with the intention and spirit. The provision of credit has become imperative not only for the trading industry but also for fiscal requirements. One way to overcome shortage by central banks is though credit control, such as the determination of maximum ratio between currency and advance cash. Therefore, a consequence of modification need in sharia bank operations, with additional specialized long-term financial instruments and institutions also required. Conventional credit controllers are ineffective for use in interest-free banking systems, with the cash ratio added to bank advances.

Tracy \& Leon (2011) elaborated on the increase in NPL in Jamaica and Tobago. In Jamaica, the problem occurred due to low-risk monitoring, while in Trinidad and Tobago, it was caused by a large amount of credit distribution. However, NPL tends to harm the loans capable of slowing down monetary expansion. A research conducted by Addae-Korankye (2014) discusses the problems of loan default issues in Ghana. It was resolved using a sampling technique on twenty-five microfinance institutions and two hundred and fifty clients, with Data collected through questionnaires and interview guides. This study found the cause of loan defaults, as follows high-interest rates, insufficient loan amount, inadequate assessment, lack of monitoring, and undue client choice. Several attempts were carried out to control 
the problems associated with these microfinance institutions, namely training before and after financing, determining reasonable interest rates, conducting customer monitoring, and providing the accuracy of the appropriate loan valuation. Besides, the government should also routinely monitor and supervise the institutions with a clear and useful link to credit policies and procedures.

Furthermore, the factors related to the internal and external inconsistencies related to NPF are also identified. Internal factors consist of low-cost efficiency, high-interest rates, inadequate loan amounts, reduced valuation, lack of supervision, improper client choices, and political misuse of the financial sector (Khan, 2008). According to Fofack (2010), high $\mathrm{NPF} / \mathrm{NPL}$ is due to a decrease in interest rates, loans, and no guarantee.

Another cause of NPL is the influence of inflation, macroeconomic, financial conditions, and GDP, which consists of household consumption and increased government expenditure. While, the internal factors are the financial ratio consisting of period payback (PP), Net Present Value (NPV), Profitability Index (PI), Internal Rate of Return (IRR), and Break-Even Point (BEP) (Kasmir, 2015). Others causes are related to solvability which includes Capital Adequacy Ratio (CAR), Financing to Deposit Ratio (FDR) on profitability, Return on Asset (ROA), operating income on expense (BOPO), the operational Efficiency ratio (OER), and Net Interest Margin (NIM) (Asnaini, 2014). Furthermore, the internal factor related to the increasing liabilities and market conditions also adds to its causes (Touny, 2015). According to Fernandez (2017), it occurs for the moral hazard to carry out credit expansion in dealing with the increasingly competitive business growth. It provides additional financing to the customer with an inadequate managerial ability in credit, assurance assessment, and monitoring. Kwambi \& Wandera (2013) show that the occurrence of bad credit caused NPL due to the obscurity of lenders, debtor, and inappropriate information in the banking industry. It was also due to increased economic growth, accident, slow refund rate, and reduced loans in the high sectors.

Also, Bruno et al. (2015) analyzed the efforts to prevent impaired credit in Italian banks. The required effort is to perform active monitoring of the entire credit portfolio, with the necessary effort to consider the best information to be monitored. Atika (2015) studied the prevention efforts of the financing problem at Sharia Bank in Indonesia while supervising, detecting, and prospective identification customers. Furthermore, disciplinary patterns and special legislation adopted in solving the bad credit on substantive legal aspects, to prevent monitoring or procedural aspects, to make an effort in changing laws associated with the banking world.

After analyzing the above problem, there is an adequate need for a useful model for the non-performance financing prevention in sharia banks by using the ANP for a better future. So, the purpose of this research is to examine the problems in non-performance financing prevention and the suitable strategies for those problems.

\section{Method}

This research type is using a qualitative and quantitative approach. It analyzes the resolution technique of non-performing finance following the $\mathrm{BI}$, OJK regulation, and Fatwa DSN, with the regulation in various countries qualitatively. The Analytic Network 
Process (ANP) was then used to analyze data using a general network model analysis (Saaty \& Vargas, 2006). It is used to determine the most appropriate effectiveness in the prevention and resolution of non-performing financing in Islamic banks.

ANP is the generalization of the Process Hierarchy Analytic (AHP), as well as part of the complex linkage between the level of decision and criteria. Its feedback approach replaces the AHP, where the relationship between levels does not easily represent high, low, dominant, or subordinate. The problem given depends on the feedback that usually generates between the criteria (Jayant, 2015). Figure 1 is a model of non-performing financing prevention in Islamic banks using ANP.

This research uses primary data obtained through in-depth interviews on nine informants consisting of regulators, academicians, and associations with a good understanding of its prevention and resolution for non-performing financing in Islamic banks with five-year experience.

Also, the ANP questionnaire that consists of three phases was distributed to 30 respondents. The initial phase forms a model construction by looking for criteria/indicators from the various literature reviews. Interviews conduct on some academic experts to assess the validity of the criteria. The second phase quantifies the model by compiling and drafting an ANP questionnaire to be assessed by scholars/academics. While in the final phase, the survey results were analyzed using decision-making software that assessed the weight of each criterion with the alternative completed by the experts. The highest value indicates the best effectiveness of the prevention and resolution methods for non-performing financing in the sharia bank.

Figure 1. Prevention Effectiveness Model of Non-Performing Financing using ANP

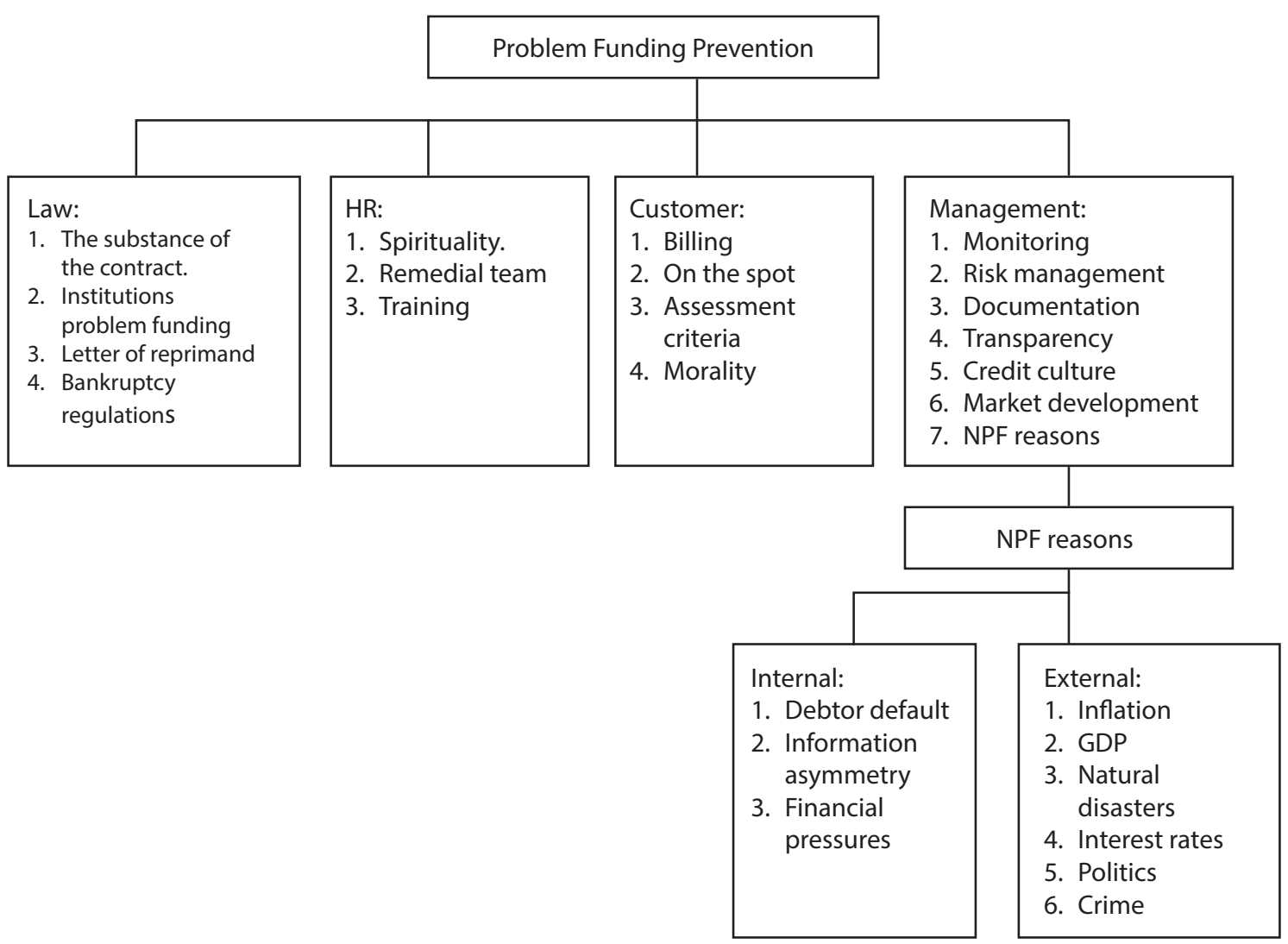




\section{Result and Discussion}

This research shows that the first prevention effectiveness to be performed is in the legal aspects, followed by the HR, customer, and management. Legal aspects are a type of prevention that should be performed by Islamic banks before conducting financing activities. This pattern consists of the contract substance, non-performing financing institutions, reprimand letters, and bankruptcy regulations.

The most important preventive measure that needs to conduct in the legal aspect is the contrast substance. According to Yulianti (2008), in preventing non-performing financing, it is necessary to build a deep understanding of the substance in sharia banks. However, it should not contradict the theory that consists of the principle of honesty and truth since it provides continuity to the existing products of Islamic banks (Yulianti, 2008). This opinion strengthens by the Association of Bankers (2014), and according to them, financing contract is due diligence with administrative properties and part of the repayment factor. Besides that, it regulates not only the obligations of both parties but also the conditions of the repayment period before maturity, while managing the requirements, warranties, representation, and others. For example, assuming the customer handed the collateral, it is certainly well documented.

The second prevention effort is to establish a non-performing financing institution. Recently, the national sharia arbitration body (Basyarnas) has become a less trusted settlement institution, with the court unable to properly synchronize with Islamic banks due to its ability to resolve general problems. For this reason, a specialized institute that handles financing problems needs to form.

The third preventive measure is by making a letter of the reprimand. According to Ibrahim \& Rahmati (2017), the letter is essential for a customer trying to boycott payment. This letter should explain the basis of the demands, what the creditor charges, and the deadlines (Rosyadi, 2017). It submits in two forms, such as to warrant (bevel) containing orders from bailiff to debtor to perform the obligation, as referred to article 1328 of civil law. Secondly, the reprimand letter contains an order of fulfillment before the deadline.

The last step in this aspect is to create bankruptcy regulations. In making legal protections, some new laws, regulations, and instruments need to be formed for the credit quality of the banking system as well as formulate the policy recovery to prevent the occurrence of non-performing financing (Parven, 2015). Besides, Anand et al. (2017), stated that no regime governs sharia bankruptcy in Indonesia, and one is needed to regulated and support the development of banks.

These prevention efforts have the capability of making Islamic banks more organized under the regulation. It also helps the human resource sector to carry out financing activity, more optimally by creating effectiveness both in distribution and billing patterns and by settling financing in Islamic banks.

The law practiced in Islamic banks should be following globalization. About five years ago, the banking business pattern was offline-based, with customers directly coming to 
banks. However, the reverse is currently the case as all payments and services turn out to be online based just by using the Internet. Conversely, the human resources of Islamic banks tend to serve customers by visiting their location. Such conditions should be updated to provide similarity in the level of business competition in the banking industry by following the developments and changes related to the rules which earlier standardized. These changes should also refer to the basic principles and changes in terms of implementation and service. Therefore, by entering the MEA (Asean Economic Community) era, Islamic banks tend to compete with the banking industry in other Asian countries, such as Malaysia, which provides the best services and facilities to customers.

Fiqh rules explain that "Fatwa changes along with changing times and circumstances." This rule explains that times and circumstances change the laws implemented in the past. However, it understands the substance of meaning contained and the purpose that to be achieved. Muamalah, which is conducted and well developed following the desired substance Syara' (Maqashid Syariah), needs to achieve the benefit of all people and avoid any harm. This type of activity is acceptable, and rejection occurs when negative influences brought on society (Rozalinda, 2016).

The central aspect of the prevention of human resources is by forming spirituality. According to Lee \& Ramsis (2011), its development should be planned and wellexecuted. Good businesses tend to facilitate the worship activity of all employees, and unit of spiritual development, which makes employees more responsible in carrying out their duties, without corruption, and manipulation. According to Herijanto (2017), the spiritual need aims to instill the principle of Tauhid as the primary foundation, with God as the absolute owner of the universe. Therefore, relating to financing, it is considered God's gift, which should always correctly control. It continues by building the principle of honesty and social justice in work, as well as Tazkiyah, which balances the world. Therefore, spirituality becomes a significant aspect of preventing the occurrence of nonperforming financing.

After forming the spirituality, it continues by forming a remedial team to arrange the financing activities and problem-solving. According to Ibrahim \& Rahmati (2017), it is carried out by forming a professional team. This division concept of labor also corresponds to the labor theory of Adam Smith (1792-1790). According to Smith, division labor encourages a specialization, where each person chooses to work according to his or her respective talents and abilities. This fact increases workforce productivity, which ultimately improves the overall product yield, with the cooperation of teams, convenience in all activities, and Allah's assistance (Amalia, 2002). As the Prophet has spoken in hadith, "the Hand of God (God's help) is in two people in cooperation, as long as there is no betrayal (Sula, 2004).

This stage also facilitates problem identification and recommends the Islamic principle of mutual help. Employees should work together in collecting job payments through division by calling the customer, making the reprimand letter, visiting customers' locations (when the call and letter have no answer), giving advice, analyzing their business, and financial condition,. They need to be able to trust each other and help give customers a reasonable 
performing payment. It is under the surah Al-Maidah verse 2, “...and help each other (virtue) in virtue and piety, and do not help in committing sins and transgressions".

The last stage in this aspect is training. According to Huda \& Nasution (2014), this improvement should be conducted to adjust short-term and long-term needs. In the short term, it is necessary to conduct education and training at each management level in Islamic banks. While for the long term, there is a particular school on Sharia HR at the undergraduate and master levels. However, no regulator controls the minimum budgetary obligations to improve the quality of human resources. Their role is to ensure the intensive provision of HR financing by providing free training for Islamic bank staff. According to Korangkye (2014), prevention needs to be carried out to ensure these HRs are skilled and dexterous through specialized training for employees in charge of financing and non-performing finance issues associated with customer satisfaction. According to Rogak (2004), trainers need to analyze the conditions and situations of employee abilities, to gain an understanding of the results of this exercise.

These three phases need to applied in Islamic banks in preventing the non-performing financing problem since the bank's activity source comes from the employee. When they fail to work adequately, professionally, and less proficient in knowing the principles of sharia, Islamic banks tend to have the same activities pattern with conventional banks, without optimal processing. For these reasons, professional power is formed from HR Islamic banks which do not only work based on orders from superiors, but sincerely, selflessly, disciplined, honestly, and responsibly.

The customer participates in determining the installment payment of finance in Islamic banks. However, this is also delayed or passed due date, which generates nonperforming financing. From the analysis, the customer is the third aspect that should develop after law and HR. It could perform through billing, on the spot, evaluation criteria, and morality.

The primary prevention on the customer aspect is by determining the billing method on the spot. According to Ibrahim \& Rahmati (2017), this needs to be carried out directly by a remedial team in the field by looking at the condition of the customer through collateral, and their business processes. The team also has to set due dates to avoid problem financing. However, it is essential to carry out customs checking on the concerned customers to ascertain they have no credit problem with another bank. Assuming the customer in question experiences problems associated with many loans from other banks, then the next identification is to analyze their monthly revenue. In this, the customer needs to make the right payment, avoid delays, or wait for the bills. As the Prophet says in a Hadith, "Deferring payment of debt for capable people is a tyranny." (H.R. Jamaah). Another Prophet's words state, "The signs of a hypocrite are ... when you break a promise". (H.R. Bukhari Muslim)

According to academics of Bank BNI Syariah and Syariah Bukopin, the requirements in credit proposal are the customer owns $70 \%$ of assets while the remaining $30 \%$ is for payment of credit installments. Therefore, suppose the customer already has a previous 
installment in another bank of IDR 500,000, and borrowed from the current bank with an installment of IDR 700,000, with a total installment of IDR 1,200,000, then the total assets owned to obtain credit conditions are equal to IDR 4,000,000. This fact is because $70 \%$ is for customer's needs; Islamic banks need to explicitly prohibit their credit applications because, when approved, it tends to pose a risk. However, the customer can pay in installments.

The third step is by assessing customer criteria. According to Kasmir (2015), it should meet the principle of 5c, namely, character, capacity, capital, condition, collateral. The application of this principle needs to be carefully conducted to acquire an excellent customer background.

The final factor in preventing non-performing financing in the HR aspect is to perform morality to the customer. It could be carried out by controlling customers and conducting financing before the approval of the manager (Herijanto, 2017). Banks need to make a great effort in determining the financing that can be approved and by monitoring businesses which have been funded (Herijanto, 2017). In this stage, Islamic banks need to advise customers regarding their awareness of the burden in paying installments and instill a sense of honesty in paying with accountability when delays experience.

According to Rozalinda (2016), all difficulties always have a way out, which should be performed by Islamic banks by improving human resources and facilities in carrying out the activities of financing distribution, payment supervision, and settling problems. As contained in the fiqh study, "All difficulties are always resolved." With the ease of prevention in this aspect, it increases the growth of Islamic banks, decreases the non-performing financing, and makes the Islamic banks with professional HR stronger than others.

Management holds an essential part in the success of Islamic banks, especially in performing financing activities, both from the management of debtors, finance, guarantees, and human resources. In this research, it becomes the last aspect of prevention after legal, human, and customers. The management aspects that need to be improved include monitoring, risk management, documentation, transparency, credit culture, market development, and NPF.

The first preventive effort in the management aspect is monitoring. It aims to form responsibility among employees and debtors under operational standards. According to the Indonesian Bankers Association (2014), monitoring of corporate credit is more stringent than retail credit or consumer. It is carried out assuming the bank is experiencing a reduction or condition that affects the quality of credit provided. In Islam, monitoring is permissible to give the attention of the parties concerned in work. It makes them feel respected and motivated, thereby reducing the possibility of fraud in the company.

According to Parven (2015), in monitoring activities, a manager needs to take active notes of all credit portfolios. It aimed at guiding the best of migration between the risk classes and the need to undertake financing coaching in minimizing the misunderstandings affecting the company performances. The second effort is on risk management. It is a part of monitoring where the approach looks at the risk possibilities. According to Mukoki (2015), 
credit risk is the leading risk that should manage. Before conducting business decisions, managers should map the risks and resolutions of each product to minimize the impact of a credit problem. Proper risk management needs to go through the process of identification and mapping, rating, confirmation of risk profile, management planning, and provide solutions (Indroes, 2008).

The risks faced by Islamic banks have a diversity based on the activities undertaken. This fact is because the harder the distribution of financing activities, the more substantial the long-term risk and the more sharia bank customers have problems, the lower the liquidity, with an increase in solvability. The Fiqh rule states, "Al Ghurmu bi Al-ghurmi," which means that the risk is in line with profit (Rozalinda, 2016). If the sharia bank wants to make a big profit and provide benefits to all customers, it should be prepared to face substantial risks. Although the problem later arises, it can solve by looking at the risk management map that has been made before, as in another rule, "al-Kharaj bid AdDhoman," meaning that the right to obtain results causes by the necessity to bear the risk (Rozalinda, 2016).

Furthermore, the third prevention effort is analyzing the document. It is essential, especially connecting to the risk mapping already made before. In this documenting process, the validity and fulfillment of legal requirements for each proposal should ascertain. The debtors have to fulfill all requirements in proposing the credit, both in installments and in cash. The provision of these requirements has made in all Islamic banks. Completeness of the documentation, according to the experts of Islamic banks, should cover the customer's data, finances, business activities, and others. The bank should not give the next step before the document is complete. The documents received should be checked for completeness. They have to immediately notify the prospective customer for the incompleteness in the document. After that, it is necessary to verify documents that have completed with a document photocopy and a legalized stamp (Laksamana, 2009).

The fourth prevention is on the transparency aspect. According to Jassud \& Kang (2015), it could prevent the financing problem through the act of honesty owned by both employees and customers. It is also part of the sunnah of Rasulullah, in which the Prophet in the trade is always transparent/honest as to the problems of the condition of goods, prices offered, billing, marketing, the arrangement of the cashflow of goods and money, partnering, and others.

Such actions need to apply to Islamic banks. The employees must be transparent in displaying all forms of activities to the manager and customer regarding the condition of goods and distribution. The customer also has to be transparent relating to payment ability. When the problem occurs, they also have to be transparent about the assets to be collateral as a substitute for the loss of Islamic banks.

The next prevention is by forming a culture of credit/financing. It will determine the qualification of the financing provision, the amount of collateral, the payment period, and others (Ning-Ning, 2007). The management should concern about the development of credit culture, which will be the direction for the staff's behavior. According to one expert 
from Bank Syariah Bukopin, banks should know the financing culture of each area and adjust it into the company target. For example, some areas like to procrastinate payments, some do not give collateral, some want the way of billing by visiting their homes, and some do not want to rebuke for the late payment for 1-2 days. Such cultures need to synchronize with the objectives of the corporate organization to minimize the risks and decrease the profit target. For this reason, Islamic banks should be able to identify cultural patterns in each location to prevent the occurrence of non-performing financing. The well-implemented credit culture will encourage the behavior of the staff to work positively.

When a culture of credit/financing has established, then Islamic banks should look at the sixth prevention effort, such as conducting market development. In this phase, the bank has given the debtor approval in the financing. Hence it should conduct the market development by conducting control of the business activities of customer routinely as well as providing solutions to problems faced by them.

Furthermore, the last prevention aspects are to look at the cause of NPF, both from the internal and external sides. Although financing has provided, Islamic banks have to anticipate the possibility of other risks arising from debtors.

In internal factors, the occurrence of NPF caused by the debtor's default, information asymmetry, and financial pressure. One of the internal factors of NPF is the default of the debtor (Umam, 2016). It is where the debtor negligent from making payments due to either intentional elements or financial limitations. All Islamic banks often experience this condition. Managers or employees who did not have good intentions in choosing customers will cause default (Hariyani, 2010)

Another factor is the asymmetry of information provided by internal parties. They provide all facilities to the prospective customer in submitting the financing but do not see the debtor's quality from the evaluation criteria. According to academics, the occurrence of information asymmetry often occurs in Islamic banks since the motives of Islamic banks today are looking for profit rather than a benefit.

According to the Bank of Mega Shariah experts, this information asymmetry can also occur from the collateral provided. It is in the form of a building and the contents used as a basis in addition for the collateral value. However, without knowledge by the bank, the customer had taken those contents, and they failed to pay. It will lead to non-performing financing and can reach the court if the customer does not acknowledge his actions. Therefore, the bank must continue to monitor all kinds of internal aspects that occur both from the employee and the customer until the fall is over. The third prevention that needs to be done by Islamic banks is the pressure (Chikoko et al., 2012) of the Islamic bank finance that requires obtaining high sales targets. It takes action outside of the established regulations.

Besides the internal factors, NPF could also cause by external reasons consisting of inflation, GDP decline, natural disasters, rising interest rates, political instability, and crime. The results of this study indicate the occurrence of NPF due to inflation. When inflation occurs, all basic prices increase that the debtor should work hard to meet the needs with 
higher expenditure. They have difficulty in paying the installments since their financial limitations are only sufficient to meet the needs of their families. This condition then will generate the non-performing financing problems. Therefore, a sharia bank should be cautious when inflation occurs against the funds that have provided to the debtors.

Then, the second factor is the decline in GDP (Parven, 2015) caused by high inflation and poor control. It makes debtors hard to get funds since their income decreased as the decreased purchasing power. They only could fulfill their daily needs and made them have the inability to pay. For this reason, many problematic financing caused by business failures. Other external factors that cause NPF are natural disasters (Parven, 2015). This incident is outside the predictions of both the debtor and the bank. From the debtor's side, business losses could occur due to fire, theft, flood, earthquake. Islamic banks can also experience this.

Furthermore, the fourth cause is an increase in interest rates by the central bank (Hariyani, 2010). This cause will affect Islamic banks in determining financing rates for debtors. If there is an increase in interest rates, Islamic banks must follow the regulations and mark up fees from the central bank for the costs of Islamic bank activities. However, the results of this accumulation will give to the customer. The determination of these fee rates for Islamic banks also does not have to have standards by not providing installment changes to customers. Therefore, it also begins with the determination of high financing rates to the debtor. They will find it challenging to make installment payments until repayment.

Santoso et al. (2019) state that the strategy formulation for handling non-performing financing divide into five levels such as goal, economic sector, factor, actor, and programs. Koju et al. (2018) suggest that high profitability and high income will lower the default risk.

The political stability also an external factor of NPF (Parven, 2015). Political problems will have the effect of high non-performing financing due to a change in leadership that will change all financing policies and regulations. For example, in the beginning, the debtor could make installment payments at the branch where he made the payment. However, due to changes in regulations, Islamic banks must close some of the branch offices that operate. With the closure of a branch office, it is difficult for customers to make payments at branch offices that are far from where they live. The last cause of the occurrence of NPF is criminality (Parven, 2015). Many criminals take the property of the debtor that they collapse and are unable to make installment payments.

\section{Conclusion}

The prevention efforts of non-performing financing (NPF) in Islamic banks are still said to be not effective due to the diverse conditions. Also, the NPF rate was still high, at 2.46 in March 2018. Therefore, the prevention efforts by providing a useful model are required. It began with establishing legal aspects by knowing the substance of the contract, establishing a new institution for non-performing finance, making a professional reprimand, and establishing bankruptcy regulations based on Islamic economics.

The secondary prevention is by forming high quality, professional human resources from a high religious perspective to create honesty and responsibility, followed by a remedial team, 
and training. Furthermore, the third prevention is carried out on the aspects of customers through billing, on the spot, direct visiting (to see costumer's house and business conditions), assessing customer criteria carefully including character, capacity, capital, condition, and collateral, as well as doing prevention on customer morality.

Management is the fourth aspect that needs to emphasize the principle of comprehensive monitoring of all operational financing activities. The internal factors for non-performing financing are information asymmetry, human resources, default, financial pressure, and customers. Meanwhile, the external factors such as inflation, GDP decline, natural disasters, increasing interest rates, and criminality politics also affect the NPF. For further research, it is necessary to apply the resolution effectiveness model of non-performing financing to minimize it in Islamic banks in Indonesia.

\section{References}

Agnes, N. (2010). Strategic Response to the Challenge Non Performing Loans By Commercial Bank of Africa. Unpublished Thesis. Nairobi: School of Business University of Nairobi.

Amalia, E. (2002). Sejarah Pemikiran Ekonomi Islam (The History of Islamic Economics Thought). Depok: Gramata Publishing.

Antonio, M. S. (2009). Dasar-dasar Manajemen Bank Syariah (The Fundamentals of Islamic Banking Management). Tangerang: Azkia Publisher.

Asnaini, S. W. (2014). Faktor-faktor yang mempengaruhi Non Perfoming Financing (NPF) pada Bank Umum Syariah di Indonesia (Factors affecting Non-Performing Financing (NPF) at Islamic Commercial Banks in Indonesia). Jurnal TEKUN, 5(2), 264-280.

Anand, G., Aditya, K. L., \& Abrianto, B. O. (2017). Problematika Aplikasi Ekonomi Syariah Dalam Rezim Hukum Kepailitan Di Indonesia (Problems of Sharia Economic Applications in the Bankruptcy Law Regime in Indonesia). Jurnal Bina Mulia Hukum, 2(1), 67-79.

Atika, J. (2015). Prinsip Kehati-hatian dalam Pencegahan Pembiayaan Bermasalah (Prudential Principle in Preventing Problem Funding). At-Tijaroh, 1(2), 22-38.

Bruno, E., Iacoviello, G., \& Lazzini, A. (2015). On The Possible Tools for the Prevention of Non-Performing Loans: A Case Study of an Italian Bank. Risk Governance \& Control: Financial Markets \& Institutions, 5(1), 7-19.

Chikoko, L., Mutambanadzo, T., \& Vhimisai, T. (2012). Insights On Non Performing Loans: Evidence From Zimbabwe Commercial Banks In A Dollarised Environment (2009-2012). Journal of Emerging Trends in Economics and Management Sciences, 3(6), 882-886.

Farooq, M., \& Zaheer, S. (2015). Are Sharia Bank More Resilient during Financial Panics?. IMF Working Paper, WP/15/41/. New York: International Monetary Fund.

Fofack, H. (2005). Nonperforming Loans In Sub-Saharan Africa: Causal Analysis And Macroeconomic Implications. World Bank Policy Research Working Paper 3769.

Handoko, T. H. (2009). Manajemen (Management). Yogyakarta: BPFE Yogyakarta. 
Hariyani, I. (2010). Restrukturisasi Penghapusan Kredit Macet (Restructuring in Writing off Bad Loans). Jakarta: Kompas Gramedia.

Hasan, Z. (2008). Credit Creation And Control: An Unresolved Issue In Islamic Banking. MPRA paper no.8130.

Herijanto, H. (2017). Moralitas Bank (Bank Morality). Jakarta: Universitas Trisakti.

Huda, N., \& Nasution, M. E. (2014) Current Issue Lembaga Kenangan Syariah (Current Issues in Islamic Financial Institutions). Jakarta: Prenada Media Group.

Ibrahim, A., \& Rahmati, A. (2017). Analisis Solutif Penyelesaian Pembiayaan Bermasalah di Bank Syariah: Kajian pada Produk Murabahah di Bank Muamalat Indonesia Banda Aceh (Solutive Analysis of Problem Solving Financing in Sharia Banks: A Study on Murabaha Products at Bank Muamalat Indonesia Banda Aceh). Iqtishadia, 10(1), 71-96.

Indroes, F. (2008). Manajemen Risiko Perbankan (Banking Risk Management). Jakarta: PT Raja Grafindo Persada.

Jassud, N., \& Kang, K. (2015). Strategy For Developing a Market For Non Performing Loans in Italy. IMF Working Paper, WP/15/24/2015.

Jayant, A., Paul, V., \& Kumar, U. (2015). Application of Analytic Network Process (ANP) in Business Environment: A Comprehensive Literature Review. IJRMET, 5(1), 29-37.

Kasmir. (2015). Dasar-Dasar Perbankan (The Basic of Banking). Jakarta: PT. Raja Grafindo Persada.

Kettle, B, (2011). Introduction Sharia Banking and Finance. United Kingdom: Design and Patents Act.

Khan, M., \& Bhatti, M. (2008). Development in Sharia Banking the case of Pakistan. New York: Palgrave Macmillan.

Khaskhelly, A. Z. (2015). Comparative Analysis of Performance of Sharia Vis a Vis Conventional Banking of Pakistan during Global Financial Crisis 2007-2010. Romanian Statistical Review Supplement, 63(3), 29-42.

Koju, L., Koju, R., \& Wang, S. (2018). Does Banking Management Affect Credit Risk? Evidence from the Indian Banking System. International Journal of Financial Studies, 6(67), 1-11.

Korankye, A. A. (2014). Causes and Control of Loan Default/Delinquency in Microfinance Institutions in Ghana. American International Journal of Contemporary Research, 4(12), 36-45.

Kwambi, K. D., \& Wandera, M. (2013). Effects Of Credit Information Sharing On Nonperforming Loans: The Case Of Kenya Commercial Bank Kenya. European Scientific Journal, 9(13), 168-193.

Laksamana, Y. (2009). Panduan Praktis Account Officer Bank Syariah (Practical Guide for Islamic Bank Account Officers). Jakarta: PT Elex Media Komputindo.

Lee, S., \& Ramsis, N. (2011). 33 Jurus Sukses Berbisnis Kala Masih Bekerja (33 Tricks of Success in Business when Still Working). Jakarta: PT. Tangga Pustaka. 
Maidalena. (2014). Analisis Faktor Non performing Financing (NPF) pada industri Perbankan Sharia (Analysis of Non-performing Financing (NPF) Factors in the Sharia Banking industry). Human Falah, 1(1), 41-50.

Mukoki, P. (2015). The Effect of Dollarization on The Growth of Non Performing Loans in The Zimbabwe Bank System: An Distributed Lag (Ardl) Bound Test Approach. Journal of Economics and Sustainable Development, 6(10), 82-92.

Nasr, S. (2007). How Sustainable and Irreversible is the Banking Sector Reform in Egypt. Proceeding at Oxford Business \& Economics Conference.

Ning-ning, G. (2007). Causes and Solutions of Non-performing Loan in Chines Commercial Banks. Chinese Busniness Review, 6(6), 13-19.

Parven, S. (2015). Non Performing Loans of Commercial Banks in Bangladesh. MPRA Paper No. 65248.

Rosyadi, I. (2017). Jaminan Kebendaan Berdasarkan Akad Syariah (Material Security Based on Sharia Agreement). Depok: Kencana.

Rozalinda. (2016). Fikih Ekonomi Syariah (Islamic Economics Jurisprudence). Jakarta: PT. Raja Grafindo Persada.

Ryu, K. P. (2012). A Comparative Study between the Sharia and Conventional Banking Systems and Its Implications. Scholarly Journal of Business Administration, 2(5),48-54.

Rogak, L. (2004). 100 Bisnis Pilihan Terbaik (100 Best Business Choices). Jakarta: PT. Elex Media Komputindo.

Saaty, T.L., \& Vargas, L.G. (2006). Decision Making with the Analytic Network Process: Economic, Political, Social and Technological Applications with Benefits, Opportunities, Costs and Risks. New York:

Santoso, M. H., Siregar, H., Hakim, D. B., \& Siregar, M. E. (2019). Strategy for NonPerforming Financing Management in Sharia Banks Based on Economic Sector of Financing. OJBM, 7(2), 374-385. https://doi.org/10.4236/ojbm.2019.72025.

Sula, M. S. (2004). Asuransi Syariah (Islamic Insurance). Jakarta: Gema Insani Press.

Sutikno, M. R. (2009). Fund Planning. Jakarta: GRASINDO.

Touny, M. A., \& Shehab, M. A. H. (2015). Macroeconomic Determinants of NonPerforming Loans: An Empirical Study of Some Arab Countries/American. Journal of Economics and Business Administration, 7(1): 11-22. https://doi.org/10.3844/ajebasp. 2015. 11.22

Tracy, M., \& Leon, H. (2011). The Impact of Non-Performing Loans on Loan Growth. Retrieved from: http://www.b6oj.org.jm/researchconf/papers/Tracey_The\%20 Impact $\% 20$ of\%20NPLs\%20on\%20Loan\%20\%20Case\%20Study\%20of\%20 Jamaica\%20\%20Trinidad\%20and\%20Tobago.pdf

Umam, K. (2016). Perbankan Syariah Dasar-dasar dan Dinamika Perkembangan di Indonesia (Islamic Banking Basics and Development Dynamics in Indonesia). Jakarta: PT. Raja Grafindo Persada. 
Wanjira, T. L. (2010). The Relationship Between Non-Performing Loans Management Practices And Financial Performance Of Commercial Banks In Kenya. Unpublished Thesis. Nairobi: School of Business, University of Nairobi.

Yulianti, R. T. (2008). Asas-asas Perjanjian (Akad) dalam Hukum Kontrak Syariah (Principles of Agreement (Contract) in Sharia Contract Law). La Riba: Jurnal Ekonomi Islam, 11(1), 91-107. 